\title{
The Importance of Physics Text Book in Connecting Concepts and Principles with Character Values and Social Attitude as well as Spiritual Attitude
}

\author{
I Wayan Santyasa ${ }^{1}$, I Wayan Suastra ${ }^{2}$. \\ ${ }^{1,2}$ Physics Department \\ Universitas Pendidikan Ganesha \\ Singaraja, Indonesia \\ ${ }^{1}$ santyasa@undiksha.ac.id, 2iwsuastra@undiksha.ac.id
}

\author{
I Gede Astawan \\ Elementary Teacher Education \\ Universitas Pendidikan Ganesha \\ Singaraja, Indonesia \\ astawan@undiksha.ac.id
}

\begin{abstract}
Physics textbooks until now only contain a tangle of concepts and principles. This study aimed to describe the importance of linking physics concepts and principles in textbooks with character values, social and spiritual attitudes. This research was conducted in 27 SMAs from 9 Regencies in Bali. Its subjects are 27 principals of the SMAs, 54 physics teachers, and 540 SMA's students. The responses of the subjects to the developed physics textbook were collected by questionnaire and analyzed descriptively. The results of the analysis showed that the physics concepts and principles in the textbooks are very important to connect with associated character values, social and spiritual attitudes. The Principals and teachers said that these are needed as a medium of learning physics which are meaningful for the students in order to be able to construct good character as well as good social and spiritual attitudes. So physics textbooks become meaningful.
\end{abstract}

Keywords-physics textbooks, concept and principle, character values, social attitudes, and spiritual attitudes

\section{INTRODUCTION}

Reliable and contextual illustrations are needed as the substance of physics textbooks. This serves as one of the ways to attract the students' interest in reading. As an illustration of the substance of physics textbook, aspects of character, social, or spiritual[1] are presented. But in reality, physics textbooks, especially those used in high school, so far only contained concepts, principles, and drill[2]. Physics textbooks which relate concepts and principles to the character values, social attitudes, and spiritual attitudes are the basis of developing the student competencies - but have not found yet in educational praxis. This is thought to be one of the underlying causes which make the students are less interested to learn physics [3, 4]. The low interest of students in learning physics will certainly affect the low of the students' learning outcomes in physics.

The results of physics study of high school students only reflect the value of knowledge and intellectual skills[5, 2, 1]. In fact, later in the real world (in society), students are expected to have not just intellectual ability. Actual life in society also requires good character, social attitudes, and spiritual attitudes[6, 7, 8, 9, 1, 10, 11, 12, 13]. Therefore, the packaging of textbooks should accommodate the needs of students not only to develop intellectual knowledge and skills, but also to build good character, develop positive social attitudes, and promote good spiritual attitudes.

Physical education praxis is implemented with the aim to familiarize the students to be able to recognize nature. Similarly, the study of physics in high school aims for students to recognize and understand the nature of themselves as humans and the universe where they stand. The world and its dynamics studied in physics, describe the Almighty God in the form of macrocosm, while humans describe the Almighty God in the form of microcosm. Students in high school who have reached the age of formal operations should have been able to think abstractly of the relationship between themselves as humans (microcosm) and the universe (macrocosm).Abstractive thinking abilities are not only oriented to intellectual ability, but also character, social attitudes, and spiritual attitudes [10]. One way to help students in developing abstractive thinking abilities is to develop physics textbooks that substantially connected to the concepts and principles of physics with the values of character, social attitudes, and spiritual attitudes.

Character values are the positive psychological aspects embodied in man. Psychologically, character values include cognitive, affective, and moral aspects of behavior [11, 10]. Cognitive values include vigilance, virtue, attractiveness in perspective, reasoning, decision making and maturity. The values of attitudes include loving and acting justice, selfrespect, empathy, loving kindness, and humility. Moral aspects of behavior include moral knowing, moral feeling, and moral action. Good character values include knowing the good, desiring the good, and doing the good. Doing good consists of habits of the mind, habits of the heart, and habits of the behavior. Moral action consists of moral competence, moral will, and moral habit.

Social attitude is the attitude to establish relationships between students. Social attitudes include the attitude of organizing groups, negotiating solutions, maintaining personal 
relationships, and conducting social analysis [2]. Social attitudes of organizing groups include initiating and coordinating efforts to mobilize people, negotiating solutions, preventing conflict and resolving conflicts, reaching agreement, overcoming or mediating disputes, proficient in diplomacy, law, reconciliation, relationships, empathy in relationships, and responding to the feelings and concerns of others, the attitude of social analysis, understanding the feelings, motives, and concerns of others.

Spiritual attitudes are attitudes which reflect students' struggles and experiences in relation to the essence of life that encompass three main dimensions: self-relation, relationship with others and the universe, and relationship with the transcendent $[7,10])$. Based on the three main dimensions, it can be differentiated as dimensions of spiritual attitudes, as follows: living a meaningful and harmonious, happy, peaceful side by side, private context community-oriented, loving environment, respect for diversity, speak positive, truthful, have a positive purpose in the life of a group, offer a good healing to others selfless love of God, has a personal relationship with God, have a cooperative spirit with others, have a sustainable prayer group, self-confidence, trust in others, trust in God.

Based on the background of the above issues, the following research questions are asked. 1) What is the principal's response to the substance of a physics textbook which links to the concepts and principles of physics with the values of character, social attitudes, and spiritual attitudes? 2) How does the physics teacher respond to the relevance of the relationship between concepts and principles of physics to the values of character, social attitudes, and spiritual attitudes that are the substance of physics textbooks? 3) What is the student's response to the relevance of the relationship between concepts and principles of physics to the values of character, social attitudes, and spiritual attitudes which are the substances of physics textbook?

\section{METHOD}

This research is conducted by survey method to describe two main things, namely 1) teacher and student response about the relevance of the relationship of concepts and principles that become the substance of physics textbook with the character values, social attitude, and spiritual attitude, 2) the response of principals, physics teachers, and high school students about the importance of physics textbooks connecting to the concepts and principles of physics with the character values, social attitudes, and spiritual attitudes.
This research was conducted on 9 regencies / cities in Bali. In each district / city 3 (three) high schools are selected, each located in urban, suburban, and in the village. Thus, this study was conducted on 27 SMA involving 27 headmasters of high school. In each SMA were selected 2 (two) physics teachers, so this study involved 54 high school physics teachers. Each physics teacher is asked to invite 10 (ten) students of class X, so there are 540 high school students involved in answering this research questionnaire.

The responses of the principals, physics teachers, and students were collected by questionnaire. The questionnaire is about the importance of physics textbooks in relation to the concepts and principles to the character values, social attitudes, and spiritual attitudes consisting of 3 (three) devices, each of which is used to collect the responses of the principals, physics teachers, and students. Each device consists of 3 (three) items. Each item of the questionnaire provided 4 (four) answer options with grading scale $4,3,2,1$. Scale 4 means very important, 3 means important, 2 means less important, and 1 means not important.

The response of physics teachers and students to the relationship of concepts and principles to the character values, social attitudes, and spiritual attitudes are collected by questionnaire. The questionnaire consists of 2 (two) devices, each of which is used to collect the responses of the physics teachers and students. Each device consists of 9 (nine) statement items. Each item is provided 4 (four) answer options with grading scale $4,3,2,1$. Scale 4 means very relevant, 3 means relevant, 2 means less relevant, and 1 means irrelevant. Research data were analyzed descriptively.

\section{FINDING}

The first thing that became the findings of this research is the exploration of the character values, social attitudes, and spiritual attitudes contained in the concepts and principles of physics. These are included as the substance of physics textbooks. This section presented 3 (three) concepts and principles of physics.

\section{A. An Example Of The Concept And Principle Of The Unit, Inertia, And Elasticity}

The results of the exploration of character values, social attitudes, and spiritual attitudes related to the concepts and principles of unit, inertia, and elasticity (i.e. only examples) which are the substance of physics textbooks are presented in Table 1. 


\section{TABLE 1.THE RELATIONSHIP BETWEEN CONCEPT AND PRINCIPLE TO THE CHARACTER VALUES,} SOCIAL ATTITUDE, AND SPIRITUAL ATTITUDE

\begin{tabular}{|c|c|c|c|c|}
\hline No & Concept and Principle & Character Values & Social Attitude & Spiritual Attitude \\
\hline 1 & $\begin{array}{l}\text { Concept of the Unit: } \\
\text { Size measurement statement, } \\
\text { comparator measurement magnitude } \\
\text { Principle of the unit: SI, MKS, CGS, } \\
\text { The value is fixed, international, } \\
\text { replicable and replicable, easily } \\
\text { converted to other units, standard units } \\
\text { are used in general, non-standard units } \\
\text { are used based on local wisdom }\end{array}$ & $\begin{array}{l}\text { Tolerance, democratic, } \\
\text { social, and caring about the } \\
\text { environment. Magnitude will } \\
\text { have no meaning if it is not a } \\
\text { unit. The presence of units to } \\
\text { complete the magnitude is a } \\
\text { character of tolerance for the } \\
\text { magnitude to have meaning. } \\
\text { The character of tolerance is } \\
\text { followed by democratic, } \\
\text { social, and environmental } \\
\text { character. }\end{array}$ & $\begin{array}{l}\text { Respect the difference and } \\
\text { accept the deal. The first } \\
\text { attitude stems from the } \\
\text { principle of unit differences } \\
\text { in the MKS and CGS } \\
\text { systems that actually have the } \\
\text { meaning of similarity in } \\
\text { difference. The second } \\
\text { attitude comes from the } \\
\text { standard principle which is a } \\
\text { manifestation of international } \\
\text { conventions. }\end{array}$ & $\begin{array}{l}\text { Caring is the drive to do something for } \\
\text { others, understanding people's needs, } \\
\text { awareness to contribute to society, and } \\
\text { awareness of wanting to benefit others. } \\
\text { Attitudes are sourced from the concept } \\
\text { and the principle of the unit whose } \\
\text { presence is very important for the concept } \\
\text { and principle of magnitude. }\end{array}$ \\
\hline 2 & $\begin{array}{l}\text { Concept of Inertia: Laziness } \\
\text { Principle of Inertia: } \\
\text { The nature of matter that tends to } \\
\text { maintain its comfort zone, which keeps } \\
\text { silent, which moves on and on. This } \\
\text { property can change if it is given a } \\
\text { push or pull from the outside. } \\
\text { Accommodation to a pull or pull from } \\
\text { the outside will make the change leave } \\
\text { the comfort zone and become dynamic } \\
\text { resulting in acceleration, a = F / m, a = } \\
\text { acceleration, F = stroke or external } \\
\text { impulse, } \mathrm{m}=\text { mass (mass = property of } \\
\text { inertia) }\end{array}$ & $\begin{array}{l}\text { Character influences through } \\
\text { the provision of motivation } \\
\text { and exemplary for adults, } \\
\text { teachers, or parents. Motivate } \\
\text { yourself with hard work, } \\
\text { creative, independent, } \\
\text { dynamic, and responsibility. } \\
\text { Hard work is a character of } \\
\text { sincerity overcoming } \\
\text { obstacles, creative is the } \\
\text { character of thinking and } \\
\text { doing something that } \\
\text { produces new ways based on } \\
\text { the potential possessed, } \\
\text { independent is the character } \\
\text { of not dependence on others, } \\
\text { dynamic is the character that } \\
\text { accepts the challenge, and the } \\
\text { responsibility is the character } \\
\text { of carrying out duties and } \\
\text { obligations. }\end{array}$ & $\begin{array}{l}\text { The attitude of acceptance } \\
\text { and confidence. A material } \\
\text { strongly influenced by its } \\
\text { inertia can accept external } \\
\text { influences. Such influences } \\
\text { can be encouragement or } \\
\text { pull. Students who are part of } \\
\text { the material that has the soul, } \\
\text { is certainly able to develop } \\
\text { the attitude of acceptance, } \\
\text { both encouragement and pull. } \\
\text { Acceptance is followed by } \\
\text { self-confidence. }\end{array}$ & $\begin{array}{l}\text { Trust, acceptance, and caring. Two things } \\
\text { related to belief are 1) attitude to } \\
\text { overcome life with all its implications, 2) } \\
\text { attitude of trying to interpret life that } \\
\text { must be accepted. Both of these attitudes } \\
\text { lead to an awareness-based acceptance } \\
\text { attitude to do something for the } \\
\text { realization of interaction, and awareness } \\
\text { to take a role in the environment. }\end{array}$ \\
\hline 3 & $\begin{array}{l}\text { Concept of Elasticity: Flexibility } \\
\text { Principle of elasticity: Although the } \\
\text { material is elastic, it is bound to inertia } \\
\text { and limitations. External influence that } \\
\text { exceeds the limit of elasticity causes } \\
\text { damage to the material. Material } \\
\text { elasticity is subject to Hook's law, that } \\
\text { there is a Hook force whose direction } \\
\text { is always opposite to outside forces. } \\
\text { Hook force tends to restore the } \\
\text { condition of being pushed or attracted } \\
\text { to its original state. }\end{array}$ & $\begin{array}{l}\text { Character of discipline, love } \\
\text { of peace, and care for the } \\
\text { environment. Discipline, is } \\
\text { the character values which } \\
\text { demonstrates orderly } \\
\text { behavior and complies with } \\
\text { various rules and regulations. } \\
\text { Peaceful love lies in the } \\
\text { elastic soul, the value of a } \\
\text { patient character that causes } \\
\text { others to feel happy and } \\
\text { secure for their presence. } \\
\text { Elastic soul has a good } \\
\text { concern, including the } \\
\text { environment. Caring for the } \\
\text { environment, it is the value } \\
\text { of a character that always } \\
\text { strives to prevent damage to } \\
\text { the surrounding natural } \\
\text { environment, and develops } \\
\text { efforts to repair the already } \\
\text { existing natural damage. }\end{array}$ & $\begin{array}{l}\text { Being honest acknowledged } \\
\text { mistakes, responsibility by } \\
\text { accepting risks and } \\
\text { willingness to apologize, } \\
\text { cooperate and willingly } \\
\text { share, cooperate sincerely. } \\
\text { Social attitudes accept } \\
\text { interaction from outside has } \\
\text { good benefits for life, } \\
\text { because defensive and } \\
\text { resistance-based efforts of } \\
\text { inertia can harm yourself, } \\
\text { others, and the natural } \\
\text { environment. }\end{array}$ & $\begin{array}{l}\text { Attitudes understand the meaning of } \\
\text { trust-based life. The attitude is sure to try } \\
\text { to make sense of what life should be } \\
\text { accepted. The attitude of acceptance and } \\
\text { consciousness that every life has its own } \\
\text { tragedy, awareness finds difficulties, } \\
\text { consciousness does things without regard } \\
\text { to consequences, cares about doing } \\
\text { something useful to others, and makes } \\
\text { meaningful contributions to society, and } \\
\text { connects with nature, senses a sensation } \\
\text { The powerful, and the spiritual activity } \\
\text { by feeling there is a higher power that } \\
\text { provides guidance in life. }\end{array}$ \\
\hline
\end{tabular}

The relationship of concept and principle of unit, inertia, and elasticity with the character values, social attitudes, and spiritual attitudes as presented in Table 1 are presented at the beginning of each chapter or sub chapter, depending on the need. Matters in concerning the importance of substance are responded by principals, physics teachers, and students. In terms of the relevance of the relationship of concept and principle of unit, inertia, and elasticity to the character values, social attitudes, and spiritual attitudes, the physics textbook is responded by physics teachers and students.

\section{B. Respond of The Principals}

The principal's response to the importance of textbooks relating concepts and principles to the character values, social attitudes, and spiritual attitudes is presented in Table 2. 
TABLE 2. RESPONSE OF THE PRINCIPALS (N=27) ON THE CONTENT OF PHYSICS TEXTBOOK

\begin{tabular}{|c|l|l|l|l|l|}
\hline No & \multicolumn{1}{|c|}{ Description } & \multicolumn{4}{c|}{ \% Responses } \\
\cline { 3 - 6 } & & $\mathbf{4}$ & $\mathbf{3}$ & $\mathbf{2}$ & $\mathbf{1}$ \\
\hline 1 & $\begin{array}{l}\text { The importance of linking concepts } \\
\text { and principles of physics with } \\
\text { character values }\end{array}$ & 74 & 26 & 0 & 0 \\
\hline 2 & $\begin{array}{l}\text { The importance of linking concepts } \\
\text { and principles of physics with social } \\
\text { attitude }\end{array}$ & 67 & 33 & 0 & 0 \\
\hline 3 & $\begin{array}{l}\text { The importance of linking concepts } \\
\text { and principles of physics with } \\
\text { spiritual attitude }\end{array}$ & 78 & 22 & 0 & 0 \\
\hline
\end{tabular}

Table 2 states that the principals' response is very important and important about the relationship of concepts and principles with character values, social attitudes, and spiritual attitudes.

\section{Respond of the Physics Teachers}

The physics teachers' response to the relevance and importance of the relationship of concepts and principles of physics to the character values, social attitudes, and spiritual attitudes is presented in Table 3 and Table 4.

TABLE 3 RESPONSE OF THE TEACHERS (N=54) ON THE RELEVANCE OF THE CONTENT

\begin{tabular}{|c|c|c|c|c|c|}
\hline \multirow[t]{2}{*}{ No } & \multirow[t]{2}{*}{ Description } & \multicolumn{4}{|c|}{ \% response } \\
\hline & & 4 & 3 & 2 & 1 \\
\hline 1 & $\begin{array}{l}\text { Relevance of the relationship between } \\
\text { concepts and principles of units with } \\
\text { character values }\end{array}$ & 65 & 30 & 5 & 0 \\
\hline 2 & $\begin{array}{l}\text { Relevance of the relationship between } \\
\text { concepts and principles of units with } \\
\text { social attitude }\end{array}$ & 70 & 24 & 6 & 0 \\
\hline 3 & $\begin{array}{l}\text { Relevance of the relationship between } \\
\text { concepts and principles of units with } \\
\text { spiritual attitude }\end{array}$ & 81 & 11 & 8 & 0 \\
\hline 4 & $\begin{array}{l}\text { Relevance of the relationship between } \\
\text { concepts and principles of inertia with } \\
\text { character values }\end{array}$ & 76 & 20 & 4 & 0 \\
\hline 5 & $\begin{array}{l}\text { Relevance of the relationship between } \\
\text { concepts and principles of inertia with } \\
\text { social attitude }\end{array}$ & 71 & 25 & 4 & 0 \\
\hline 6 & $\begin{array}{l}\text { Relevance of the relationship between } \\
\text { concepts and principles of inertia with } \\
\text { spiritual attitude }\end{array}$ & 73 & 20 & 7 & 0 \\
\hline 7 & $\begin{array}{l}\text { Relevance of the relationship between } \\
\text { concepts and principles of elasticity with } \\
\text { character values }\end{array}$ & 75 & 25 & 0 & 0 \\
\hline 8 & $\begin{array}{l}\text { Relevance of the relationship between } \\
\text { concepts and principles of elasticity with } \\
\text { social attitude }\end{array}$ & 70 & 30 & 0 & 0 \\
\hline 9 & $\begin{array}{l}\text { Relevance of the relationship between } \\
\text { concepts and principles of elasticity with } \\
\text { spiritual attitude }\end{array}$ & 66 & 30 & 4 & 0 \\
\hline
\end{tabular}

Table 3 states that physics teacher response is categorized as high relevant and relevant about the relationship of concepts and principles with character values, social attitudes, and spiritual attitudes.
TABLE 4. RESPONSE OF THE TEACHERS (N=54) ABOUT THE IMPORTANCE OF THE CONTENT

\begin{tabular}{|c|l|c|c|c|c|}
\hline No & \multicolumn{1}{|c|}{ Description } & \multicolumn{4}{|c|}{ \% response } \\
\cline { 3 - 6 } & & $\mathbf{4}$ & $\mathbf{3}$ & $\mathbf{2}$ & $\mathbf{1}$ \\
\hline 1 & $\begin{array}{l}\text { The importance of linking concepts and } \\
\text { principles of physics with character } \\
\text { values }\end{array}$ & 67 & 33 & 0 & 0 \\
\hline 2 & $\begin{array}{l}\text { The importance of linking concepts and } \\
\text { principles of physics with social attitude }\end{array}$ & 78 & 22 & 0 & 0 \\
\hline 3 & $\begin{array}{l}\text { The importance of linking concepts and } \\
\text { principles of physics with spiritual } \\
\text { attitude }\end{array}$ & 83 & 17 & 0 & 0 \\
\hline $4=$ 4ery important, 3=important, 2=less important, 1=not important \\
\hline
\end{tabular}

Table 4 states that the physics teachers' response is very important and important about the relationship of concepts and principles with character values, social attitudes, and spiritual attitudes.

\section{Respond of the Students}

The students' response to the relevance and importance of the relationship of concepts and principles of physics to the character values, social attitudes, and spiritual attitudes is presented in Table 5 and Table 6.

TABLE 5. RESPONSE OF THE STUDENTS (N=540) ON THE RELEVANCE OF THE CONTENT

\begin{tabular}{|c|c|c|c|c|c|}
\hline \multirow[t]{2}{*}{ No } & \multirow[t]{2}{*}{ Description } & \multicolumn{4}{|c|}{ \% response } \\
\hline & & 4 & 3 & 2 & 1 \\
\hline 1 & $\begin{array}{l}\text { Relevance of the relationship between } \\
\text { concepts and principles of units with } \\
\text { character values }\end{array}$ & 68 & 28 & 4 & 0 \\
\hline 2 & $\begin{array}{l}\text { Relevance of the relationship between } \\
\text { concepts and principles of units with } \\
\text { social attitude }\end{array}$ & 72 & 24 & 4 & 0 \\
\hline 3 & $\begin{array}{l}\text { Relevance of the relationship between } \\
\text { concepts and principles of units with } \\
\text { spiritual attitude }\end{array}$ & 85 & 10 & 5 & 0 \\
\hline 4 & $\begin{array}{l}\text { Relevance of the relationship between } \\
\text { concepts and principles of inertia with } \\
\text { character values }\end{array}$ & 70 & 25 & 5 & 0 \\
\hline 5 & $\begin{array}{l}\text { Relevance of the relationship between } \\
\text { concepts and principles of inertia with } \\
\text { social attitude }\end{array}$ & 78 & 20 & 2 & 0 \\
\hline 6 & $\begin{array}{l}\text { Relevance of the relationship between } \\
\text { concepts and principles of inertia with } \\
\text { spiritual attitude }\end{array}$ & 76 & 20 & 4 & 0 \\
\hline 7 & $\begin{array}{l}\text { Relevance of the relationship between } \\
\text { concepts and principles of elasticity with } \\
\text { character values }\end{array}$ & 72 & 25 & 3 & 0 \\
\hline 8 & $\begin{array}{l}\text { Relevance of the relationship between } \\
\text { concepts and principles of elasticity with } \\
\text { social attitude }\end{array}$ & 66 & 32 & 2 & 0 \\
\hline 9 & $\begin{array}{l}\text { Relevance of the relationship between } \\
\text { concepts and principles of elasticity with } \\
\text { spiritual attitude }\end{array}$ & 74 & 22 & 4 & 0 \\
\hline
\end{tabular}

Table 5 states that the students' responses are categorized highly relevant and relevant about the relationship of concepts and principles of physics to the character values, social attitudes, and spiritual attitudes. 
TABLE 6. RESPONSE OF THE STUDENTS (N=540) ON THE IMPORTANCE OF THE CONTENT

\begin{tabular}{|c|l|c|c|c|c|}
\hline No & \multicolumn{1}{|c|}{ Description } & \multicolumn{3}{|c|}{ \% response } \\
\cline { 3 - 6 } & & $\mathbf{4}$ & $\mathbf{3}$ & $\mathbf{2}$ & $\mathbf{1}$ \\
\hline 1 & $\begin{array}{l}\text { The importance of linking concepts and } \\
\text { principles of physics with character } \\
\text { values }\end{array}$ & 63 & 30 & 7 & 0 \\
\hline 2 & $\begin{array}{l}\text { The importance of linking concepts and } \\
\text { principles of physics with social attitude }\end{array}$ & 74 & 18 & 8 & 0 \\
\hline 3 & $\begin{array}{l}\text { The importance of linking concepts and } \\
\text { principles of physics with spiritual } \\
\text { attitude }\end{array}$ & 70 & 25 & 5 & 0 \\
\hline $\begin{array}{l}\text { 4=very important, 3=important, 2=less important, 1=not } \\
\text { important }\end{array}$ & \\
\hline
\end{tabular}

Table 6 states that the students' responses are categorized very important and important about the relationship of concepts and principles of physics to the character values, social attitudes, and spiritual attitudes.

\section{DISCUSSION}

Physical learning in schools focuses more on mathematical aspects, less emphasis on concepts and principles, and rarely has effort to cultivate values of character, social attitudes, and spiritual attitudes. One reason is that physics books used by the students tend to contain only concepts, principles, and drill. The purpose of this study is to describe the responses of principals, physics teachers, and students about the relevance and importance of physics textbooks linking concepts and principles with character values, social attitudes, and spiritual attitudes.

The results show that the principal states that substantially physics textbooks are not sufficient to contain only concepts, principles and drill, but it is also important to relate them to the character values, social attitudes, and spiritual attitudes. The principal's response was reinforced by the responses of physics teachers and students that physics textbooks thought they were important to relate the concepts and principles of physics to the character, social attitudes, and spiritual attitudes. The relationship between concepts and principles of physics with the character values, social attitudes, and spiritual attitudes described in physics textbooks, according to physics teachers and students is very important.

These findings suggest that physics textbooks which relate physics concepts and principles to values of character, social attitudes, and spiritual attitudes become very meaningful. This finding is consistent with previous findings, that learning to ignore the last three aspects is an attempt to provide opportunities for students to build meaningful ethical and spiritual lives, and better character [14].

The substance of such books can serve as a basis for learning in the classroom. The emphasis of concept and principle of physics is important in learning, because the concepts and principles also have a strategic role in shaping students' understanding of the nature of physics. However, it will become more important and meaningful if a deep understanding of the concepts and principles of physics is enriched with the description of the relationship of understanding to build good character, social attitudes, and spiritual attitudes in the study of physics. Therefore, learning physics in high school should be oriented more on the study of the relationship of concept and principle with the values of character, social attitudes, and spiritual attitudes. This is important, so that students will be better prepared to live in the real world that cannot be separated from others, the universe as a place to stand, and its relationship with God.

In the study of Hinduism, it is mentioned that God exists in every object in both moving and immovable universes $[15,16$, 17]. The meaning contained in these sacred texts indicates that God is the soul of the macro and the micro nature. Physics is a branch of science that studies matter and energy. Substance describes nature, while energy describes its natural soul. This is in accordance to the opinion of universe observers and their laws as follows: 1) Henry Beston declared that universe is a part of humanity, a man who does not understand it has bad character and attitude; 2) Goethe states that universe is life, the existence of God can be seen, 3) Reid argues that universe law is a rule created according to the resulting impact; 4) Longfellow also argues that the laws of universe are just, though frightening; 5) Charles Dickens states that universe gives beauty throughout the ages; 6) Alfred Street declares that universe is the master of mankind [18]. The expert's views of "universe" though tend to be theological bases that have limited scientific value, but give an indication of how important it is for humans to learn the nature of universe and its laws. Scientifically, the nature of "universe" can be explained by two studies, 1) ontologically, that the nature of universe is composed of substances that are the basic components, 2) epistemologically, that universe as knowledge can be learned through the scientific process. Both studies can be accommodated in physics, at both the secondary and college levels.

In the context of complete human development, the synergy between scientific and theological studies of the nature of universe is needed, so that it can give rise to a welfare of theology of science [11]. Although the study of physics can describe the relationship between the micro and the macro, but the characteristics of the relationship is very complex. Every concept and principle of physics has an interesting secret to build the characters, social attitudes, and spiritual attitudes of students $[19,20,21]$. These three things are very important for students when they are in the community as a developer of physics-based science and technology. Development of science and technology based on the character values, social attitude, and good spiritual attitude is the desire of society in order to realize a good civilization. Therefore, physics textbooks which connected to the concepts and principles of physics with the character values, social attitudes, and spiritual attitudes become very strategic. In the short term, the benefit is to enrich the content of learning resources and physics learning devices in schools, so that physics learning has an orientation not only limited to the meaning of science and technology, but also build awareness of the importance of civilization that wraps character, social attitudes, and good spiritual attitudes. In the long run, this textbook becomes a pilot for the importance of critical and creative thinking in creating meaningful and relevant learning facilities in life. 


\section{CONCLUSIONS AND SUGGESTIONS}

The conclusions of this study are as follows. 1) According to the principal, the substance of physics textbooks is very important linking the concepts and principles of physics with the character values, social attitudes, and spiritual attitudes. 2) According to the physics teacher, the relationship of concepts and principles of physics to the character values, social attitudes, and spiritual attitudes that become substances into the substance of physics textbook is very relevant. Physics teachers also claim that the substance of physics textbooks is very important to relate the concepts and principles of physics to the character values, social attitudes, and spiritual attitudes. 3) According to the student, the relationship of concepts and principles of physics with the character values, social attitudes, and spiritual attitudes which become the substance of physics textbooks, is highly relevant. The students also stated that the substance of physics textbooks is very important to connect the concepts and principles of physics with the character values, social attitudes, and spiritual attitudes.

The results of this study can be used as the basis of policy by the principal in supervising physics teachers, that the development of physics textbooks is very important to connect the concept and principles of physics with the values of character, social attitudes, and spiritual attitudes. To the students it is suggested that in studying physics not only aims to build intellectual ability, but also fosters the character values, social attitudes, and spiritual attitudes, so the physics learning becomes meaningful and relevant for life in the real world.

\section{REFERENCES}

[1] Santyasa, I W. 2015. Spirituality-based physics education: To familiarize the physical aspect with religiosity values in achieving harmony. Paper. Presented in National Seminar on Science Education and Spirituality, Them: "The role of science, education, and spirituality in harmonizing the relation of man, nature, and God", December, 19 2015, in Universitas Pendidikan Ganesha.

[2] Santyasa, I W., Sukra Warpala, I W., \& Tegeh, I M. 2014. Need assessment ofthe development of student centered learning models toimproveSMA students reasoning and character. Jurnal Pendidikan Indonesia. 3(1). 299-312.

[3] Adadan, E., Irving, K. E., \& Trundle, K. C.2009. Impacts of multiple-representational instruction on high school students' conceptual understanding of the particulate nature of matter. International Journal of Science Education, 31, 1743-1755.

[4] Baran, M. 2016. An analysis on high school students' perceptions of physics courses in terms of gender (a sample from Turkey). Journal of Education and Training Studies. 4(3): 150-160. http://dx.doi.org.

[5] Chamodro-Premuzic, T. \& Furnham, A. 2005. Intellectual competence. The Psychologist. 18(6). 352-354.

[6] Lewis, C., Watson, M., \& Schaps, E. 1999. Recapturing education's full mission: Educating for social, ethical, and intellectual development. In Regeluth, C. M. (Ed.): Instructional design theories and model: A new paradigm of instructional theory. 511-535. United States of America: Lawrence ErlboumAssociates, Inc.

[7] Meezenbroek, E. D. J., Garssen, B., Berg, M. P. D., Tuytel, G., Dierendonck, D. V.,Visser, A., Schaufeli, W. B. 2012.Measuring spirituality as a universal humanexperience: Development of the spiritualattitude and involvement list (SAIL). Journal of Psychosocial Oncology, 30:141-167.

[8] Moore, J. 1999. Adolescent spiritual development: Stages and strategies. In Regeluth, C. M. (Ed.): Instructional design theories and model: A new paradigm of instructional theory. 613-651. United States of America: Lawrence ErlboumAssociates, Inc.
[9] Ogawa, B. \& Min, D. 2007. Cultural and spiritual competence. National Victim Assistance Academy, Track 1, Foundation-Level Training.

[10] Santyasa, I W., Sukra Warpala, I W., \& Tegeh, I M. 2015. Validationand implementationof student centered learning models to improve SMA students'reasoningandcharacter. Jurnal Pendidikan Indonesia. 3(1). 299-312.

[11] Santyasa, I W. 2016(a). Explorationof character values, social attitude, andspiritual attitudeon thephysics concept and principle. Paper. Presentedon theNational Seminar ofMathematics and SciencesandEducation", July, 30 2016, in Inna Bali Beach Sanur Denpasar.

[12] Santyasa, I W. 2016(b). Content description and prescription of character in physics education in the era of MEA. Paper. Presented in the Seminar of Education "Building young generation in the Era of MEA based on the character education, November, 27 2016, in Universitas Pendidikan Ganesha.

[13] Welsh, J. A. \& Bierman, K. L. 2010. Social Competence. Online article. $\quad$ http://findarticles.com/p/articles/mi_ g2602/is_0004/ai_2602000487/.

[14] Singh, T. D. 2008. The science of interreligious dialogue. Kolkata: The Bhaktivedanta Institute.

[15] Griffith, R. T. H. 2005. Yajurveda Samhita. Perterjemah: Dewanto, S. S. Surabaya: Paramita.

[16] Wiana, I K. 2006. Love to the universeis devotionof God. Surabaya: Paramit.

[17] Pudja, G. 1999. Bhagawad-Gita: Pancamo Veda. Surabaya: Paramita.

[18] Singh, T. D. 2015. Man \& nature: Scientific \& Vedantic perspectives. Kolkata: The Bhaktivedanta Institute.

[19] Egan, K. 2001. Spirituality, education, and the moral life. Paper. Delivered to the AERA conference held in Seattle, WA, on April 10-

[20] Singh, T. D. 2004. Seven noble laureates on science and spirituality. Kolkata: The Bhaktivedanta Institute.

[21] Ahang, A. 2014. The relationship between spiritual intelligence and anxiety mediate the religious attitude in undergraduate students of Islamic Azad University, farscienceandresearchbranch. Indian Journal of Fundamental and Applied Life Sciences, 4(S4): 977-989. 